\title{
Hajj pilgrims' knowledge about Middle East respiratory syndrome coronavirus, August to September 2013
}

P Gautret (philippe.gautret@club-internet.fr) ${ }^{1,2}$, S Benkouiten ${ }^{1,2}$, I Salaheddine ${ }^{2}$, K Belhouchat $^{2}$, T Drali $^{1}$, P Parola $^{1,2}$, P Brouqui $^{1,2}$

1. Aix Marseille Université, Unité de Recherche sur les Maladies Infectieuses et Tropicales Emergentes (URMITE), Marseille, France

2. Institut Hospitalo-Universitaire Méditerranée Infection, Pole Maladies Infectieuses, Assistance Publique Hôpitaux de Marseille, Marseille, France

Gautret P, Benkouiten S, Salaheddine I, Belhouchat K, Drali T, Parola P, Brouqui P. Haji pilgrims' knowledge about Middle East respiratory syndrome coronavirus, August to September 2013. Euro Surveill. 2013;18(41):pii=20604. Available online: http://www.eurosurveillance.org/ViewArticle.aspx?Articleld=20604

In preparation for Hajj 2013, 360 French pilgrims were interviewed regarding their knowledge about Middle East respiratory syndrome (MERS). Respondents were aged 20-85 years, male-female ratio was 1.05:1; $64.7 \%$ were aware of the MERS situation in Saudi Arabia; $35.3 \%$ knew about the Saudi Ministry of Health recommendations for at-risk pilgrims to postpone participation in the 2013 Hajj. None of 179 at-risk individuals (49.9\%) decided to cancel their Hajj participation even after advice during consultation.

\section{Background}

After its emergence in June 2012 [1], most cases of Middle East respiratory syndrome coronavirus (MERS(oV) infections were reported from Saudi Arabia (SA) [2] where the Hajj, the largest religious mass gathering takes place annually. A rapid acquisition of respiratory viruses, most notably rhinovirus was evidenced in $39 \%$ of French pilgrims suffering respiratory symptoms soon after commencing the $2012 \mathrm{Hajj}$, with $11 \%$ returning infected to France with potential spreading of these respiratory viruses [3]. No case of MERS-CoV nasal carriage was evidenced in this cohort, despite high rates of respiratory symptoms [4]. International spread of Neisseria meningitis infections by Hajj pilgrims has occurred in the past which prompted the requirement for meningococcal vaccination before participating in the pilgrimage [5]. The Hajj is expected to draw over three million pilgrims from within Saudi Arabia and around the world. Given the predicted population movements out of Saudi Arabia, there may be a potential for worldwide spread of MERS-CoV [6].

For the 2013 Hajj, the Saudi Ministry of Health (MoH) recommends that elderly people, above 65 years of age, and those with chronic diseases e.g. heart disease, kidney disease, respiratory disease and diabetes and pilgrims with immune deficiency such as congenital and acquired, malignancies and terminal illnesses, pregnant women and children (under 12) coming for Hajj and Umrah this year, postpone the performance of the Hajj and Umrah for their own safety [7].
Early results of the first week of 2013 mandatory meningococcal vaccination campaign for Hajj at our institution (19 to 25 August 2013) showed that $48 \%$ of pilgrims preparing for Hajj this year had at least one disorder for which the Saudi $\mathrm{MoH}$ recommends to postpone the performance of the Hajj [8]. These results prompted us to perform a knowledge, attitudes, and practices (KAP) survey that addressed MERS and its prevention among Hajj pilgrims presenting subsequently at our travel clinic.

\section{Knowledge, attitudes, and practices survey among Hajj pilgrims}

We conducted a KAP survey that addressed MERS and its prevention among Hajj pilgrims during four weeks, from 26 August to 22 September 2013. The study was based on a standardised questionnaire designed specifically by our team and comprising 15 items including demographics, previous participation to the Hajj, chronic conditions, pregnancy, vaccination status, knowledge about MERS and preventive measures against respiratory infections. A total of 360 persons (184 men, 176 women, ratio 1.05:1) aged 20-85 years (mean: 58 years) who attended our outpatient clinic as part of a pre-Hajj meningococcal vaccination campaign, were invited to participate in a face to-face interview during which a medical doctor completed the questionnaire. A $100 \%$ participation rate was achieved in the given period. Most pilgrims were born in North Africa $(89.4 \%)$, had lived in France for more than 20 years (70.0\%) and were traveling to Saudi Arabia for the first time $(76.9 \%)$. A total of $49.2 \%$ had at least one condition for which the Saudi MoH recommends to postpone the performance of the $2013 \mathrm{Hajj}$ (Table 1); 64.7\% of the respondents were aware of an ongoing MERS epidemic in SA and 35.3\% were aware of the Saudi $\mathrm{MoH}$ recommendations for at risk pilgrims to postpone performing the Hajj in 2013. Even though women pilgrims were statistically significantly less in the $>65$ years age group, there was no difference for the co-morbidities except for immune deficiency. 


\begin{tabular}{|c|c|c|c|c|}
\hline & $\begin{array}{l}\text { Pilgrims in } \\
\text { preparation for the } \\
\text { Hajj }(\mathrm{N}=360)\end{array}$ & $\begin{array}{c}\text { Men } \\
(n=184)\end{array}$ & $\begin{array}{l}\text { Women } \\
(\mathrm{n}=176)\end{array}$ & $\begin{array}{l}\text { p value } \\
\text { (men vs women) }\end{array}$ \\
\hline $\begin{array}{l}\text { Mean age in years (min-max) } \\
>65 \text { years } \\
<12 \text { years }\end{array}$ & $\begin{array}{c}58.3(20-85) \\
111(30.8 \%) \\
0(0.0 \%)\end{array}$ & $\begin{array}{c}58.5(20-85) \\
74(40.4 \%) \\
0(0.0 \%)\end{array}$ & $\begin{array}{c}58.1(22-79) \\
37(21.0 \%) \\
0(0.0 \%)\end{array}$ & $\begin{array}{l}0.767 \\
<10^{-3} \\
\text { NA }\end{array}$ \\
\hline Any co-morbidity & $116(32.2 \%)$ & $56(30.4 \%)$ & $60(34.1 \%)$ & 0.458 \\
\hline Diabetes & $83(23.1 \%)$ & $40(21.7 \%)$ & $43(24.4 \%)$ & 0.544 \\
\hline Chronic kidney disease & $1(0.3 \%)$ & $0(0 \%)$ & $1(0.6 \%)$ & 0.489 \\
\hline Chronic heart disease & $34(9.4 \%)$ & $15(8.2 \%)$ & $19(10.8 \%)$ & 0.391 \\
\hline Chronic lung disease & $17(4 \cdot 7 \%)$ & $8(4.3 \%)$ & $9(5.1 \%)$ & 0.732 \\
\hline Malignant disease & $0(0.0 \%)$ & $0(0.0 \%)$ & $0(0.0 \%)$ & NA \\
\hline Immune deficiency & $6(1.7 \%)$ & $0(0.0 \%)$ & $6(3.4 \%)$ & 0.013 \\
\hline Pregnancy & $1(0.3 \%)$ & NA & $1(0.6 \%)$ & NA \\
\hline $\begin{array}{l}\text { At least one condition for which the Saudi Ministry of Health } \\
\text { recommends to postpone the performance of the Hajj }\end{array}$ & $179(49.9 \%)$ & $99(54.1 \%)$ & $80(45.5 \%)$ & 0.102 \\
\hline
\end{tabular}

NA: not applicable.

Among 179 at risk individuals (99 men, 80 women), none decided to cancel their participation to the Hajj after even after advice during consultation. However, when informed about the potential effectiveness of prevention measures against respiratory infection (use of face masks and disposable tissue, hand hygiene, social distancing and avoiding touching eyes, nose and mouth) most pilgrims (90.1\%) were willing to apply such measures (Table 2).

\section{Conclusions}

Although our results cannot be extrapolated to all Hajj pilgrims, they show that pilgrims departing from southern France were unaware of the ongoing MERS epidemic and of the Saudi $\mathrm{MoH}$ recommendations before consulting a specialised travel clinic. However, such information was relayed by the French $\mathrm{MoH}$ in July 2013 to hospital healthcare providers, specialised travel agencies, and Muslim authorities, and was extensively covered in French newspapers. Moreover, despite receiving special advice about these issues during the pre-Hajj consultation in our specialised centre, at-risk pilgrims maintained their decision to participate in the 2013 Hajj. Although this was not documented in our survey, it could be that some pilgrims declined to change their plans because they had already arranged and paid for their travel before. Furthermore, it is possible that those pilgrims who come to our clinic are more health-conscious compared to pilgrims who received their mandatory vaccine from their general practitioner. Nevertheless, the latter group may also comprise a considerable number of at-risk individuals. Risk perception in the context of the Hajj is very likely influenced by cultural and religious beliefs. Identifying effective communication strategies for necessary preventive measures in the context of religious mass gatherings would be of high value for public health authorities those providing healthcare and advice to individuals. With the exception of travel restriction for at-risk individuals, a high acceptability rate towards individual preventive measures was observed among pilgrims which confirm previous results conducted in 2009 [9] and this should be noted during pre-travel advice consultations.

\section{Conflict of interest}

None declared.

\section{Authors' contributions}

Philippe Gautret: study design, result interpretation, writing manuscript; Samir Benkouiten: statistics, analysing results, reviewing manuscript; Imane Salaheddine: data collection; Khadidja Belhouchat: data collection; Tassadit Drali: data collection; Philippe Parola: reviewing manuscript; Philippe Brouqui: reviewing manuscript.

\section{TABLE 2}

Acceptability of preventives measures Hajj pilgrims, France, August-September $2013(n=360)$

\begin{tabular}{|l|c|}
\hline Acceptability of preventives measures & $n(\%)$ \\
\hline Use of face mask & $314(87.2 \%)$ \\
\hline Hand washing & $343(95.3 \%)$ \\
\hline Use of hand disinfectant & $333(92.5 \%)$ \\
\hline Use of disposable tissue & $337(93.6 \%)$ \\
\hline Avoiding contact with ill people & $310(86.1 \%)$ \\
\hline Avoiding touching eyes, nose and mouth & $310(86.1 \%)$ \\
\hline
\end{tabular}

Source of preventive measures: [7]. 


\section{References}

1. Zaki AM, van Boheemen S, Bestebroer TM, Osterhaus AD, Fouchier RA. Isolation of a novel coronavirus from a man with pneumonia in Saudi Arabia. N Engl J Med. 2012;367(19):181420. http://dx.doi.org/10.1056/NEJMoa1211721. PMid:23075143.

2. Penttinen PM, Kaasik-Aaslav K, Friaux A, Donachie A, Sudre B, Amato-Gauci AJ, et al. Taking stock of the first 133 MERS coronavirus cases globally - Is the epidemic changing? . Euro Surveill. 2013;18(39):pii=20596. Available from: http://www. eurosurveillance.org/ViewArticle. aspx?Articleld=20596. PMid:24094061.

3. Benkouiten S, Charrel R, Belhouchat K, Drali T, Salez N, Nougairede A, et al. Circulation of respiratory viruses among pilgrims during the 2012 Haji Pilgrimage. Clin Infect Dis. 2013:57(7):992-1000. http://dx.doi.org/10.1093/cid/cit446. PMid:23839997.

4. Gautret P, Charrel R, Belhouchat K, Drali T, Benkouiten S, Nougairede A, et al. Lack of nasal carriage of novel corona virus (HCOV-EMC) in French Hajj pilgrims returning from the Haji 2012, despite a high rate of respiratory symptoms. Clin Microbiol Infect. 2013;19(7):E315-7. http://dx.doi. org/10.1111/1469-0691.12174. PMid:23452263.

5. Abubakar I, Gautret P, Brunette GW, Blumberg L, Johnson $D$, Poumerol G, et al. Global perspectives for prevention of infectious diseases associated with mass gatherings. Lancet Infect Dis. 2012;12(1):66-74. http://dx.doi.org/10.1016/ S1473-3099(11) 70246-8

6. Khan K, Sears J, Hu VW, Brownstein JS, Hay S, Kossowsky D, et al. Potential for the international spread of Middle East respiratory syndrome in association with mass gatherings in Saudi Arabia. PLoS Curr. 2013;5.

7. World Health Organization (WHO). Health conditions for travellers to Saudi Arabia for the pilgrimage to Mecca (Haji). Wkly Epidemiol Rec. 2013;88(32):343-7. PMid:24040674.

8. Gautret P, Benkouiten S, Salaheddine I, Parola P, Brouqui P. Preventive measures against MERS-CoV for Haji pilgrims. Lancet Infect Dis. 2013;13(10):829-31. http://dx.doi. org/10.1016/S1473-3099(13)70259-7

9. Gautret P, Soula G, Parola P, Brouqui P. Hajj pilgrims' knowledge about acute respiratory infections. Emerg Infect Dis. 2009;15(11):1861-2. http://dx.doi.org/10.3201/ eid1511.090201. PMid:19891890. PMCid:PMC2857473. 